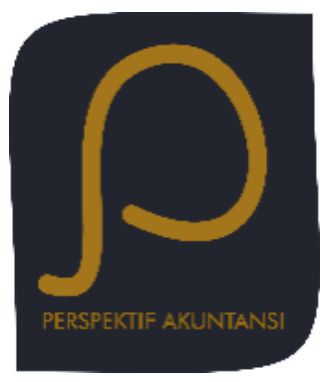

Perspektif Akuntansi

Volume 4 Nomor 2 (Juni 2021), hal. 105-119

ISSN: 2623-0194 (Print), 2623-0186 (Online)

Copyright(C The Authors(s). All Rights Reserved

Center for Accounting Development and Research (CARD)

Fakultas Ekonomika dan Bisnis,

Universitas Kristen Satya Wacana

DOI: https://doi.org/10.24246/persi.vXiX.p105-119

http://ejournal.uksw.edu/persi

\title{
Pengaruh Pajak Daerah, Retribusi Daerah, Lain-Lain PAD yang Sah, dan DAK Terhadap Belanja Modal
}

\author{
Sonia Murti ${ }^{1}$ \\ Rina Trisnawati \\ Universitas Muhammadiyah Surakarta
}

Received

$06 / 04 / 2021$

Abstract. Capital Expenditure is a component of direct spending in

Revised

$25 / 04 / 2021$ the government budget which has an important role in running the government system to improve the welfare of the community and as

\section{Accepted}

26/04/2021 a form of good governance. This research aims to know the effect of local taxes, local levies, other legal local revenues, special allocation funds on Capital Expenditure in all regency/city of Central Java Province using data from 2016-2019. Total sample are 81 regency/city.Results of this research show that Local Tax and Special Allocation Fund significantly influenced to Capital Expenditure, while Local Levies and other legal local revenues has not significantly influenced to Capital Expenditure.

Keywords: Local Tax, Local Levies, other legal local revenues, Special Allocation Fund, Capital Expenditure 


\begin{abstract}
Abstrak. Belanja Modal adalah komponen belanja langsung dalam anggaran pemerintah yang mempunyai peranan penting dalam menjalankan sistem pemerintahan untuk meningkatkan kesejahteraan masyarakat dan sebagai wujud dari good governance. Penelitian ini dilakukan untuk mengetahui pengaruh pajak daerah, retribusi daerah, lain-lain PAD yang sah dan dana alokasi khusus terhadap belanja modal pada seluruh kabupaten/kota Provinsi Jawa Tengah dengan tahun pengamatan 2016-2018. Jumlah sampel sebanyak 81. Hasil dari penelitian ini menunjukan bahwa Pajak Daerah dan Dana Alokasi Khusus berpengaruh terhadap Belanja Modal, sedangkan variabel Retribusi Daerah dan Lain-lain PAD yang sah tidak berpengaruh terhadap Belanja Modal.
\end{abstract}

Kata kunci: Pajak Daerah, Retribusi Daerah, Lain-lain PAD yang sah, Dana Alokasi Khusus, dan Belanja Modal

\title{
Pendahuluan
}

Desentralisasi fiskal dapat diartikan sebagai suatu proses penyerahan kewenangan fiskal atau keuangan dari pemerintah pusat ke pemerintah daerah. Dengan adanya desentralisasi fiskal, yang tadinya harus diputuskan oleh pemerintah pusat kini dapat diputuskan di tingkat pemerintah daerah tanpa adanya campur tangan pemerintah pusat. Terdapat dua manfaat desentralisasi fiskal, yaitu efisiensi ekonomis dan peluang meningkatkan penerimaan pajak dari pajak daerah (Bahl, 2008). Optimalisasi penerimaan daerah tersebut harus jelas tercantum dalam APBD sebagai media perencanaan penerimaan, pembiayaan dan pengeluaran pembangunan daerah yang berarti pengalokasian anggaran pemerintah daerah harus lebih diperuntukan bagi kepentingan publik, misalnya dalam hal Belanja Modal. Belanja Modal adalah komponen belanja langsung dalam anggaran belanja pemerintah yang menghasilkan output berupa aset tetap.

Kementerian Keuangan melaporkan, realisasi Belanja Modal sepanjang periode 20142019 rata-rata tumbuh 4,1\% per tahun. Dibandingkan jenis belanja kementerian dan lembaga lainnya, pertumbuhan Belanja Modal paling rendah. Belanja barang tumbuh 14,3\%, Belanja Pegawai 9,5\% dan Belanja sosial 27\% (Kontan.co.id-Jakarta). Dengan demikian peneliti mengambil topik PAD apakah akan berpengaruh terhadap naiknya presentase realisasi Belanja Modal setiap daerah jika pemerintah daerah mengoptimalkan PAD pada daerahnya. Sumber-sumber penerimaan pada PAD (Pendapatan Asli Daerah) seperti yang tercantum dalam Undang-Undang No.33 tahun 2004 terdiri dari empat sumber yaitu Pajak Daerah, Retribusi Daerah, Hasil Pengelolaan Kekayaan Daerah yang Dipisahkan dan Lain-lain Pendapatan Asli Daerah yang Sah.

Pajak daerah berdasarkan Undang-Undang No.28 tahun 2009 pasal 1 ayat (1) tentang pajak daerah dan retribusi daerah. Pajak daerah adalah iuran wajib yang dilakukan oleh orang pribadi atau badan kepada daerah tanpa imbalan langsung yang seimbang 
yang dapat dipaksakan berdasarkan peraturan perundang-undangan yang berlaku, yang digunakan untuk membiayai penyelenggaraan dan pembangunan pemerintah daerah.

Pajak Daerah adalah kontribusi yang wajib dibayarkan oleh orang pribadi atau badan ke kas daerah tanpa mendapat balas jasa secara langsung yang bersifat memaksa dan digunakan untuk keperluan daerah bagi sebesar-besarnya kemakmuran rakyat (Mardiasmo, 2011:12). Sedangkan Retribusi Daerah seperti yang tercantum dalam Undang-Undang Nomor 28 tahun 2009 tentang Pajak Daerah dan Retribusi Daerah, Retribusi Daerah merupakan pungutan daerah sebagai pembayaran atas jasa atau pemberian izin yang khusus disediakan atau diberikan oleh Pemerintah Daerah untuk kepentingan orang pribadi atau badan. Berbeda dengan Pajak, Retribusi bersifat balas jasa yang dapat dirasakan langsung oleh masyarakat sebagai prestasi atas jasa yang telah diberikan oleh pemerintah bagi mereka yang membutuhkan. Retribusi Daerah dapat digunakan secara penuh oleh pemerintah daerah sebagai pemasukan untuk anggaran belanja daerah.

Lain-lain Pendapatan Asli Daerah yang Sah merupakan seluruh pendapatan daerah selain Pendapatan Asli Daerah (PAD) dan pendapatan transfer yang meliputi hibah, dana darurat dan lain-lain pendapatan sesuai dengan ketentuan peraturan perundang-undangan (Undang-Undang No.23 tahun 2014 tentang Pemerintah Daerah). Pendapatan ini merupakan penerimaan daerah yang berasal dari lain-lain milik pemerintah daerah seperti penjualan kekayaan daerah, jasa giro, penerimaan atas tuntutan ganti kerugian daerah, ataupun bentuk lain sebagaimana akibat dari penjualan atau pengadaan barang dan jasa daerah.

Di sisi lain, kemampuan besar sebagian daerah yang tercermin dalam PAD hanya mampu mengumpulkan tidak lebih dari 15\% nilai APBD. Oleh karena itu di bantu oleh pemerintah pusat melalui dana perimbangan yaitu DBH, DAU, dan DAK. Pengertian DAK diatur dalam pasal 1 angka 23 Undang-undang No.33 tahun 2004 tentang Perimbangan Keuangan antara Keuangan Pusat dan Keuangan Daerah, yaitu dana yang bersumber dari pendapatan APBN yang dialokasikan kepada daerah tertentu dengan tujuan untuk membantu mendanai kegiatan khusus yang merupakan urusan daerah dan sesuai dengan prioritas nasional.

Berdasarkan uraian di atas, penelitian ini berfokus pada pengaruh Pajak Daerah, Retribusi Daerah, Lain-lain PAD yang sah, dan DAK terhadap Belanja Modal, untuk mendapatkan bukti empiris adanya pengaruh faktor-faktor tersebut terhadap Belanja Modal jika pemerintah daerah mengoptimalkan pendapatan daerah mereka khususnya pada Provinsi Jawa Tengah. 


\section{Telaah Pustaka}

\section{Teori Keagenan}

Teori Keagenan menyatakan bahwa hubungan keagenan merupakan sebuah persetujuan atau kontrak di antara dua pihak, yaitu prinsipal dan agen, yaitu prinsipal memberi wewenang kepada agen untuk mengambil kepuasan atas nama prinsipal (Jensen dan Meckling, 1976:5). Teori Keagenan dalam sektor publik adalah hubungan keagenan antara rakyat dengan pemerintah daerah yang berupa hubungan yang terjadi karena adanya kontrak atau persetujuan yang ditetapkan oleh rakyat sebagai prinsipal dan menggunakan pemerintah sebagai agen untuk menyiapkan jasa (Jensen dan Meckling, 1976). Prinsipal merupakan pihak yang bertindak sebagai pemberi perintah dan bertugas untuk mengawasi, memberikan penilaian dan masukan atas tugas yang telah dijalankan oleh agen. Sedangkan agen adalah pihak menerima dan menjalankan tugas sesuai kehendak prinsipal (Firman 2016).

Bergman dan Lane (1990) menyatakan bahwa kerangka hubungan prinsipal agen merupakan suatu pendekatan yang sangat penting untuk menganalisis komitmenkomitmen kebijakan publik. Miriam Budiarjo (1994) mendefinisikan akuntabilitas sebagai pertanggungjawaban pihak yang diberi mandat itu, dalam konteks organisasi sektor publik sama dengan yang dijelaskan Mardiasmo (2002) bahwa pengertian akuntabilitas sebagai kewajiban pemegang amanah atau pemerintah untuk memberikan pertanggungjawaban, menyajikan, melaporkan dan mengungkapkan segala aktivitas dan kegiatan yang menjadi tanggungjawabnya kepada pihak pemberi amanah atau masyarakat yang memiliki hak untuk meminta pertanggungjawaban.

\section{Pajak Daerah}

Soeparman dalam (Waluyo, 2007:3) menyatakan pajak adalah iuran wajib berupa uang atau barang yang dipungut oleh penguasa berdasarkan norma-norma hukum guna menutup biaya produksi barang-barang dan jasa kolektif dalam mencapai kesejahteraan umum. Pajak sendiri memiliki dua fungsi, yaitu sebagai budgeter, karena pajak sebagai salah satu sumber penerimaan terpenting pemerintah untuk membiayai pengeluaran-pengeluaran dan pajak berfungsi sebagai regulatory, yaitu sebagai alat pengatur kegiatan ekonomi masyarakat.

\section{Retribusi Daerah}

Retribusi Daerah adalah pungutan daerah sebagai pembayaran atas jasa atau pemberian izin tertentu yang khusus disediakan oleh pemerintah daerah untuk kepentingan orang pribadi atau suatu badan (Undang-Undang Nomor 28 tahun 2009 tentang Pajak Daerah dan Retribusi Daerah). Dalam retribusi, adanya pembayaran dari masyarakat sebagai prinsipal kepada agen yaitu pemerintah akan memberi jasa timbal balik secara langsung yang tertuju kepada individu yang membayar. 


\section{Lain-lain PAD yang Sah}

Lain-lain Pendapatan daerah yang sah merupakan seluruh pendapatan daerah selain pendapatan asli daerah dan pendapatan transfer, yang meliputi hibah, dana darurat, dan lain-lain pendapatan sesuai dengan ketentuan peraturan perundang-undangan (UU 23 tahun 2014 tentang Pemerintah Daerah). Pendapatan ini juga merupakan penerimaan daerah yang berasal dari lain-lain milik pemerintah daerah seperti penjualan kekayaan daerah, jasa giro, penerimaan atas tuntutan ganti kerugian daerah, ataupun bentuk lain sebagaimana akibat dari penjualan atau pengadaan barang dan jasa daerah (Ramlan et al. , 2016). Pemerintah sebagai agen mendapatkan penerimaan sebagian dari hubungan yang terjadi karena adanya kontrak atau persetujuan yang ditetapkan oleh prinsipal dan menggunakan pemerintah sebagai agen untuk menyiapkan jasa, seperti sewa.

\section{Dana Alokasi Khusus (DAK)}

Menurut Peraturan Pemerintah Nomor 55 tahun 2005 tentang Dana Perimbangan pada pasal 1 angka 24 menyebutkan bahwa "Dana Alokasi Khusus yang selanjutnya disebut DAK adalah dana yang bersumber dari pendapatan APBN yang dialokasikan kepada daerah tertentu dengan tujuan untuk membantu mendanai kegiatan khusus yang merupakan urusan daerah dan sesuai dengan prioritas nasional". Pemerintah daerah sebagai agen akan menggunakan dana alokasi khusus ini untuk pembangunan fasilitas berjangka panjang guna mendukung fasilitas prinsipal yang telah menyumbang banyak pendapatan daerah sehingga mendapatkan dana khusus dari pemerintah pusat.

\section{Belanja Modal}

Menurut Abdullah (2013) Belanja Modal adalah komponen belanja langsung dalam anggaran pemerintah yang menghasilkan output berupa aset tetap. Belanja modal digunakan untuk pengeluaran dalam rangka pembelian atau pengadaan aset tetap berwujud yang mempunyai masa manfaat lebih dari 12 bulan untuk digunakan dalam kegiatan pemerintahan seperti dalam bentuk tanah, peralatan, mesin, gedung/bangunan, irigasi, jaringan dan aset tetap lainnya. Pemerintah daerah akan merealisasikan Belanja Modal kepada masyarakat dalam bentuk fasilitas publik yang tanpa masyarakat sadari berasal dari iuran yang mereka bayarkan sebagai bentuk dari tanggungjawab dan penyedia jasa.

\section{Pengembangan Hipotesis}

\section{Pengaruh Pajak Daerah terhadap Belanja Modal.}

Dalam UU Nomor 28 tahun 2009 tentang pajak dan retribusi daerah, disebutkan bahwa pajak daerah adalah iuran wajib yang dilakukan oleh orang pribadi atau badan kepada daerah tanpa imbalan langsung yang seimbang dan dapat dipaksakan berdasarkan peraturan perundang-undangan yang berlaku, dan digunakan untuk membiayai penyelenggaraan pembangunan daerah, jika masyarakat rutin membayar pajak secara langsung akan menambah keuangan daerah sehingga bisa digunakan 
untuk membiayai pengeluaran-pengeluaran daerah untuk meningkatkan pelayanan publik. Masyarakat sebagai prinsipal membayar rutin pajak agar pemerintah sebagai agen dapat menggunakan iuran pajak tersebut untuk memfasilitasi kegiatan publik yang secara tidak langsung didapatkan masyarakat sebagai bentuk tanggungjawab. Pernyataan tersebut didukung dengan penelitian yang dilakukan oleh Sudika dan Budiartha (2017) yang menjelaskan bahwa Pajak Daerah berpengaruh positif terhadap Belanja Modal. Berdasarkan pernyataan diatas maka dapat diajukan Hipotesis sebagai berikut:

$\boldsymbol{H}_{1}$ : Pajak Daerah berpengaruh terhadap Belanja Modal.

\section{Pengaruh Retribusi Daerah terhadap Belanja Modal.}

Peningkatan mutu dan pelayanan pemerintah kepada masyarakat dapat ditingkatkan apabila pendapatan yang dimiliki pemerintah daerah dari retribusi juga memadai. Pemerintah disini sebagai agen akan melaksanakan tanggungjawabnya sesuai dengan prinsipal yaitu masyarakat yang membayar dana sesuai dengan perizinan yang diajukan masyarakat atau badan tersebut. Menjadi bagian dari PAD, retribusi daerah dianggap dapat meningkatkan Belanja Modal daerah karena komponen peningkatan Belanja Modal sendiri salah satunya berasal dari PAD. Pernyataan tersebut didukung dengan penelitian yang dilakukan oleh Runtu et al. (2016) yang menjelaskan bahwa Retribusi Daerah berpengaruh positif terhadap Belanja Modal. Berdasarkan pernyataan diatas maka dapat diajukan Hipotesis sebagai berikut:

$\boldsymbol{H}_{2}$ : Retribusi Daerah berpengaruh terhadap Belanja Modal.

\section{Pengaruh Lain-lain PAD yang sah terhadap Belanja Modal.}

Sesuai pasal 26 ayat (4) Peraturan Menteri Dalam Negeri nomor 13 tahun 2006 tentang Pedoman Pengelolaan Keuangan Daerah disediakan untuk menganggarkan penerimaan daerah yang tidak termasuk dalam jenis pajak daerah, retribusi daerah dan hasil pengelolaan kekayaan daerah yang dipisahkan. Pendapatan ini merupakan penerimaan daerah yang berasal dari lain-lain milik pemda. Kelompok lain-lain dalam pendapatan daerah seperti hasil penjualan alat berat dan barang jasa, penerimaan dari sewa, bunga simpanan giro dan bank, serta penerimaan dari denda kontraktor. Agen (pemerintah) mendapatkan penerimaan sebagian dari hubungan yang terjadi karena adanya kontrak atau persetujuan yang ditetapkan oleh rakyat sebagai prinsipal dan menggunakan pemerintah sebagai agen untuk menyiapkan jasa, seperti sewa. Pernyataan ini didukung dengan penelitian yang dilakukan oleh Ramlan et al. (2016) yang menjelaskan bahwa Lain-lain PAD yang sah berpengaruh positif terhadap Belanja Modal. Berdasarkan pernyataan diatas maka dapat diajukan Hipotesis sebagai berikut:

$\boldsymbol{H}_{3}$ : Lain-lain PAD yang sah berpengaruh terhadap Belanja Modal. 


\section{Pengaruh Dana Alokasi Khusus (DAK) terhadap Belanja Modal}

Dana transfer yang bersumber dari pendapatan APBN yang dialokasikan kepada daerah tertentu untuk mendanai kegiatan khusus masalah urusan daerah dan sesuai dengan prioritas nasional. Semakin besar transfer pemerintah pusat kepada pemerintah daerah menandakan semakin meningkatnya belanja modal daerah tersebut. Tujuan DAK untuk mengurangi beban biaya kegiatan khusus yang harus ditanggung oleh pemerintah daerah. Pemanfaatan DAK diarahkan kepada kegiatan investasi pembangunan,pengadaan, peningkatan, perbaikan sarana dan prasarana fisik pelayanan publik dengan umur ekonomis lebih dari satu tahun. Dengan diarahkannya pemanfaatan DAK untuk kegiatan tersebut diharapkan dapat meningkatkan pelayanan publik yang direalisasikan dalam belanja modal (Ardhani, 2011). Bertujuannya untuk membiayai kebutuhan sarana dan prasarana masyarakat yang belum mencapai standar, peran agen disini adalah merealisasikan dana alokasi khusus untuk belanja modal yang berbentuk aset tetap seperti infrastruktur jalan, irigasi, dll yang memiliki umur ekonomis lebih dari satu tahun. Argumen tersebut didukung dengan penelitian yang dilakukan oleh Wandira (2013) yang menjelaskan bahwa Dana Alokasi Khusus (DAK) berpengaruh positif terhadap Belanja Modal. Berdasarkan pernyataan diatas maka dapat diajukan Hipotesis sebagai berikut:

$\boldsymbol{H}_{4}$ : Dana Alokasi Khusus (DAK) berpengaruh terhadap Belanja Modal.

\section{Metoda}

Peneliti mengambil sampel pada Provinsi Jawa Tengah karena sesuai dengan tempat tinggal peneliti dan untuk tahun 2016-2018 Jawa Tengah belum ada yang meneliti. Populasi pada penelitian ini adalah seluruh kabupaten/kota di Provinsi Jawa Tengah yang melaporkan secara rutin laporan realisasi APBD setiap tahunnya, menurut laporan yang dirilis situs DJPK KemenKeu jumlah kabupaten/kota di Provinsi Jawa Tengah terdiri dari 29 kabupaten dan 6 kota. Jadi populasi pada penelitian ini adalah 105 kabupaten/kota selama 2016 hingga 2018.

Penelitian ini menggunakan data sekunder berupa Laporan Realisasi APBD. Data diakses melalui situs DJPK KemenKeu dari tahun 2016-2018. Peneliti meneliti tahun 2016-2018 karena Laporan Realisasi APBD pada situs KemenKeu belum ter update untuk tahun 2019-2020, jadi peneliti memundurkan tahun penelitiannya. Penelitian ini menggunakan metode analisis regresi linier berganda, yang bertujuan untuk mengetahui ada atau tidak pengaruh Pajak Daerah, Retribusi Daerah, Lain-lain PAD yang sah, dan Dana Alokasi Khusus (DAK) terhadap Belanja Modal. Analisis regresi linier berganda yaitu menggunakan pooled data mulai dari tahun 2016-2018 dan diolah menggunakan program bantuan SPSS (Statistical Package for Social Sciences). Metode pengambilan sampel pada penelitian menggunakan teknik sampling jenuh. Namun dalam penelitian ini terdapat data yang masuk sebagai outlier berjumlah 24 data sehingga sampel akhir yang yang digunakan dalam penelitian ini berjumlah 81 kabupaten/kota dari tahun 2016-2018. 


\section{Hasil dan Pembahasan}

Penelitian ini menganalisis pengaruh pajak daerah, retribusi daerah, lain lain penerimaan daerah yang sah dan dana alokasi khusus terhadap belanja modal. Analisis data menggunakan regresi linear berganda. Adapun hasil analisisnya dapat dijelaskan sebagai berikut ini.

\section{Hasil}

\section{Hasil Statistik Deskriptif}

Berdasarkan Tabel 1 dapat dijelaskan bahwa Nilai minimum pada variabel Belanja Modal terdapat pada Kota Tegal (2018) sedangkan nilai maksimum pada Kota Semarang (2018).

\section{Tabel 1. Hasil Statistik Deskriptif}

\begin{tabular}{|c|c|c|c|c|c|}
\hline & $\mathrm{N}$ & & & & \\
\hline $\begin{array}{l}\text { Pajak } \\
\text { Daerah }\end{array}$ & 81 & 0 &, 00 & $L$ & 8530 \\
\hline $\begin{array}{r}\text { Retri } \\
\text { Dae }\end{array}$ & 81 & 5642331979,00 & $\begin{array}{c}123215026 \\
00\end{array}$ & 544,0 & 627,5 \\
\hline $\begin{array}{l}\text { Lain- } \\
\text { PAD } \\
\text { Sa }\end{array}$ & 81 & $86 / 5$ & 4231966 & $\begin{array}{c}197164596642 \\
9382\end{array}$ & $\begin{array}{l}90683891,0 \\
6165\end{array}$ \\
\hline DAK & 81 & $\begin{array}{r}79584094 \\
0\end{array}$ & $\begin{array}{r}4838134 \\
00\end{array}$ & 2820854 & $\begin{array}{r}10396 \\
13\end{array}$ \\
\hline $\begin{array}{l}\text { Belanja } \\
\text { Modal }\end{array}$ & 81 & $\begin{array}{c}113622507976 \\
00\end{array}$ & $\begin{array}{c}1228459434270 \\
, 00\end{array}$ & $\begin{array}{c}406101256113 \\
0371\end{array}$ & $\begin{array}{c}181338789744 \\
04977\end{array}$ \\
\hline
\end{tabular}

Sumber: Data diolah (2020)

Nilai minimum pada variabel Pajak Daerah terdapat pada Kota Magelang (2016) sedangkan nilai maksimum pada Kota Semarang (2018).Nilai minimum pada variabel Retribusi Daerah terdapat pada Kota Magelang (2018) sedangkan nilai maksimum pada Kota Semarang (2016). Nilai minimum pada variabel Lain-lain PAD yang sah terdapat pada Kota Pekalongan (2018) sedangkan nilai maksimum pada Kabupaten Cilacap (2017).Nilai minimum pada variabel Dana Alokasi Khusus terdapat pada Kota Semarang (2018) sedangkan nilai maksimum pada Kabupaten Cilacap (2016).

\section{Hasil Uji Asumsi Klasik}

Uji normalitas menggunakan Uji Kolmogrov-Smirnov. Hasil analisis menunjukkan nilai prob value K-S sebesar 0,625 (lebih besar dari nilai signifikansi 0.05). Hal ini menunjukkan bahwa data dalam penelitian ini berdistribusi normal. Hasil uji multikolinearita, heteroskedastisitas dan autokorelasi dapat dijelaskan pada Tabel 2,3 dan 4 berikut ini. 
Tabel 2. Hasil Uji Multikolinearitas

\begin{tabular}{cccc}
\hline Variabel & $\begin{array}{c}\text { Nilai } \\
\text { Tolerance }\end{array}$ & Nilai VIF & Hasil Analisis \\
\hline Pajak Daerah & 0,267 & 3,743 & Tidak Terjadi Multikolinearitas \\
Retribusi Daerah & 0,313 & 3,193 & Tidak Terjadi Multikolinearitas \\
Lain-lain PAD & 0,594 & 1,682 & Tidak Terjadi Multikolinearitas \\
$\quad$ yang sah & & & \\
Dana Alokasi & 0,684 & 1,462 & Tidak Terjadi Multikolinearitas \\
Khusus & & & \\
\hline
\end{tabular}

Sumber: Data diolah (2020)

Berdasarkan Tabel 2 di atas menunjukkan bahwa masing masing nilai VIF $<10$ dan Tolerance $>0.10$. maka dapat disimpulkan bahwa variabel pajak daerah, retribusi daerah, lain-lain PAD yang sah dan dana alokasi khusus tidak terjadi multikolinearitas.

Tabel 3. Hasil Uji Heterokesdastisitas

\begin{tabular}{ccc}
\hline Variabel & Sig & Hasil Analisis \\
\hline Pajak Daerah & 0,132 & Tidak Terkena Heterokesdastisitas \\
Retribusi Daerah & 0,424 & Tidak Terkena Heterokesdastisitas \\
Lain-lain PAD yang & 0,863 & Tidak Terkena Heterokesdastisitas \\
sah & & \\
Dana Alokasi Khusus & 0,650 & Tidak Terkena Heterokesdastisitas \\
\hline
\end{tabular}

Berdasarkan hasil di Tabel 3 tersebut dapat dijelaskan bahwa semua variabel menunjukkan nilai sig lebih besar dari (2-tailed) >0,05 (Ghozali,201:142:143). Dengan nilai masing-masing variabel independen yaitu Pajak Daerah 0,132, Retribusi Daerah 0,424, Lain-lain PAD yang sah 0,863, dan Dana Alokasi Khusus 0,650. Sehingga dapat disimpulkan bahwa variabel independen pada penelitian ini bebas dari heteroskedastisitas.

\section{Tabel 4. Hasil Uji Autokorelasi}

\begin{tabular}{cc}
\hline Run Test & Hasil Analisis \\
\hline 0,738 & Tidak ada Autokorelasi \\
\hline
\end{tabular}

Sumber: Data diolah (2020)

Untuk mendeteksi gejala autokorelasi dapat menggunakan uji Run Test, jika lebih dari 0,05 tidak terkena autokorelasi. Berdasarkan Tabel 4 diatas, menunjukkan bahwa $0,738>0,05$ berarti tidak ada autokorelasi. 


\section{Pengujian Hipotesis}

\section{Tabel 5. Hasil Analisis Regresi Linier Berganda}

\begin{tabular}{ccccc}
\hline Variabel & Koefisien Regresi & thitung & Sig & Keterangan \\
\hline Konstanta & 94954611277,094 & 1,977 & 0,052 & \\
Pajak & 0,639 & 4,545 & 0,000 & Berpengaruh \\
Daerah & & & & \\
Retribusi & 0,418 & 0,332 & 0,741 & Tidak Berpengaruh \\
Daerah & & & & \\
$\begin{array}{c}\text { Lain-lain } \\
\text { PAD yang }\end{array}$ & 0,265 & 1,058 & 0,293 & Tidak Berpengaruh \\
sah & & & & \\
Dana & 0,606 & 4,008 & 0,000 & Berpengaruh \\
Alokasi & & & & \\
Khusus & 29,547 & & & \\
F hitung & 0.000 & 4,545 & & \\
Prob F & 0,609 & & & \\
R & 0,588 & & & \\
Adjusted R & Sumber: Data diolah $(2020)$ & & &
\end{tabular}

Berdasarkan Tabel 5 di atas maka diperoleh persamaan regresi sebagai berikut:

$(B M)=94954611277,094+0,639 P A D+0,418 R D+0,265 \mathrm{LPAD} Y S+0,606 \mathrm{DAK}+\mathrm{e}$

Persamaan tersebut menunjukkan bahwa seluruh koefisien bertanda positif. Ini berarti jika variabel Pendapatan Asli Daerah, Retribusi Daerah, PAD lain lain yang sah dan DAK meningkat maka Belanja Modal di daerah tersebut juga akan meningkat. Selanjutnya Hasil uji adjusted $\mathrm{R}^{2}$ adalah sebesar 0,588 yang berarti sebesar 58,8\% variabel dependen yaitu belanja modal dapat dijelaskan oleh variabel independen yaitu Pajak Daerah, Retribusi Daerah, Lain-lain PAD yang sah, dan Dana Alokasi Khusus(DAK). Sisanya sebesar 41,2\% Belanja Modal dijelaskan oleh variabel lain diluar model. Nilai F hitung menunjukkan angka sebesar 29, 547 dengan nilai prob 0.000. Hal ini menunjukkan bahwa variabel Pajak Daerah, Retribusi Daerah, Lain-lain PAD yang sah, dan Dana Alokasi Khusus(DAK) berpengaruh secara simultan terhadap variabel Belanja Modal dan model regresi adalah robust.

\section{Pembahasan}

Hasil pada analisis regresi berganda diatas dapat diinterpretasikan sebagai berikut:

\section{Pengaruh Pajak Daerah terhadap Belanja Modal di Provinsi Jawa Tengah.}

Pada Hipotesis $1\left(\mathrm{H}_{1}\right)$ dalam penelitian ini yaitu variabel Pajak Daerah pengujian menunjukan bahwa $\mathrm{H}_{1}$ ini diterima. Artinya bahwa Pajak Daerah berpengaruh terhadap Belanja Modal. Hasil dari pengujian ini sama dengan Hipotesis yang sudah disebutkan bahwa semakin tinggi Pajak Daerah maka akan semakin tinggi tingkat Belanja Modal yang diperoleh pemerintah daerah tersebut. Dalam hal ini, jika masyarakat rutin membayar pajak secara langsung akan menambah keuangan daerah sehingga bisa digunakan untuk membiayai pengeluaran-pengeluaran daerah untuk meningkatkan pelayanan publik. 
Dengan penjelasan tersebut dapat disimpulkan bahwa Pajak Daerah berpengaruh terhadap Belanja Modal. Hasil pada penelitian ini sama dengan hasil penelitian oleh Sudika dan Budiartha (2017) yang menyebutkan bahwa Pajak Daerah berpengaruh paling besar dibanding retribusi daerah. Untuk lebih meningkatkan penerimaan belanja modal, pemerintah diharapkan mampu lebih mengoptimalkan penerimaan komponen-komponen dari pendapatan asli daerah yaitu pajak daerah, retribusi daerah, dan lain-lain pendapatan daerah yang sah. Dengan meningkatnya belanja modal akan memberikan dampak pada kemakmuran rakyat.

\section{Pengaruh Retribusi Daerah terhadap Belanja Modal di Provinsi Jawa Tengah.}

Pada Hipotesis $2\left(\mathrm{H}_{2}\right)$ dalam penelitian ini yaitu variabel Retribusi Daerah pengujian menunjukan bahwa $\mathrm{H}_{2}$ ini ditolak. Artinya bahwa Retribusi Daerah tidak berpengaruh terhadap terhadap Belanja Modal. Penelitian ini membuktikan bahwa belum sepenuhnya retribusi daerah kabupaten/kota di Jawa Tengah digunakan untuk alokasi belanja modal karena masih rendahnya kesadaran masyarakat dan pengelola fasilitas untuk membayar dan melaporkan biaya fasilitas umum yang digunakan, dengan dana hasil retribusi daerah sendiri digunakan untuk memperbaiki fasilitas umum tersebut. Pemerintah Jawa Tengah kurang efektif dalam mengelola retribusi tersebut, padahal retribusi sendiri wajib dibayarkan bagi wisatawan atau masyarakat manapun yang masuk kedalam suatu daerah tersebut, bisa dalam bentuk tiket masuk objek wisata atau menggunakan jasa-jasa seperti perpustakaan daerah, parkir, kebersihan, pasar tradisional dan fasilitas pelayanan publik lainnya. Kesadaran masyarakat dan kejujuran pihak pengelola sangat dibutuhkan untuk mendukung retribusi daerah meningkat dan menjadi pemasukan daerah yang potensial selain pajak daerah.

Dengan penjelasan tersebut maka dapat disimpulkan bahwa Retribusi Daerah tidak berpengaruh terhadap Belanja Modal. Penelitian ini menghasilkan hasil yang sama dengan penelitian yang dilakukan oleh Handayani., S P HS, dkk (2015) yang menyebutkan bahwa Retribusi Daerah tidak berpengaruh terhadap Belanja Modal. Hal ini terjadi karena adanya anggapan yang menekankan dan memperjelas bahwa masyarakat memandang retribusi sebagai bagian dari program bukan sebagai pendapatan pemerintah daerah dan bersedia membayar hanya bila tingkat layanan dirawat dan ditingkatkan (Queen, 1998).

Pengaruh Lain-Lain PAD yang sah terhadap Belanja Modal di Provinsi Jawa Tengah.

Pada Hipotesis $3\left(\mathrm{H}_{3}\right)$ dalam penelitian ini yaitu variabel Lain-Lain PAD yang sah pengujian menunjukan bahwa $\mathrm{H}_{3}$ ini ditolak. Artinya bahwa Lain-Lain PAD yang sah tidak berpengaruh terhadap Belanja Modal. Yang berarti bahwa kabupaten/kota di Jawa Tengah kurang dalam mengelola aset daerah mereka. Sebagai contoh, seperti menjual barang yang sudah tidak layak pakai, mengelola penerimaan sewa, dan pintar-pintar bendahara daerah masing-masing untuk menindak tegas oknum atau badan yang telat untuk membayar pajak daerah, retribusi daerah, dan keterlambatan 
pelaksanaan pekerjaan serta mencari potensi selain PAD guna menambah pendapatan daerahnya.

Jika dana lain-lain PAD yang sah meningkat, dapat digunakan sewaktu-waktu untuk keadaan darurat daerah jika terjadi bencana, sehingga dapat meningkatkan alokasi belanja modal daerah tersebut dan meningkatkan kualitas pelayanan publik lebih baik. Dengan penjelasan tersebut dapat disimpulkan bahwa Lain-lain PAD yang sah tidak berpengaruh terhadap Belanja Modal. Hasil pada penelitian ini sama dengan hasil penelitian yang dilakukan oleh Nurdiwaty et al. (2017) yang menyatakan bahwa Lain-lain PAD yang sah tidak berpengaruh terhadap Belanja Modal.

\section{Pengaruh Dana Alokasi Khusus (DAK) terhadap Belanja Modal di Provinsi Jawa Tengah.}

Pada Hipotesis $4\left(\mathrm{H}_{4}\right)$ dalam penelitian ini yaitu variabel Dana Alokasi Khusus (DAK) pengujian menunjukan bahwa $\mathrm{H}_{4}$ ini diterima. Artinya bahwa Dana Alokasi Khusus (DAK) berpengaruh terhadap Belanja Modal. Jika dana transfer yang bersumber dari pendapatan APBN yang dialokasikan kepada daerah tertentu untuk mendanai kegiatan khusus masalah urusan daerah dan sesuai dengan prioritas nasional semakin besar dari pusat menandakan semakin meningkatnya belanja modal daerah tersebut. Dengan penjelasan tersebut dapat disimpulkan bahwa Dana Alokasi Khusus (DAK) berpengaruh terhadap Belanja Modal. Hasil pada penelitian ini sama dengan hasil penelitian yang dilakukan oleh Wandira (2013) yang menyatakan bahwa Dana Alokasi Khusus (DAK) berpengaruh terhadap Belanja Modal.

\section{Simpulan}

Berdasarkan pengujian dan pembahasan pada bab sebelumnya, dapat diperoleh kesimpulan, variabel Pajak Daerah berpengaruh terhadap Belanja Modal dengan nilai signifikan yang dihasilkan 0,000 0,05 (nilai signifikan kurang dari 5\%) sehingga disimpulkan bahwa H1 diterima. Variabel Retribusi Daerah tidak berpengaruh terhadap Belanja Modal dengan nilai signifikan yang dihasilkan 0,741 < 0,05 (nilai signifikan lebih dari 5\%) sehingga disimpulkan bahwa H2 ditolak. Variabel Lain-lain PAD yang sah berpengaruh terhadap Belanja Modal dengan nilai signifikan yang dihasilkan 0,293 > 0,05 (nilai signifikan lebih dari 5\%) sehingga disimpulkan bahwa H3 ditolak. Variabel Dana Alokasi Khusus berpengaruh terhadap Belanja Modal dengan nilai signifikan yang dihasilkan 0,000 > 0,05 (nilai signifikan kurang dari 5\%) sehingga disimpulkan bahwa H4 diterima.

Saran bagi peneliti selanjutnya adalah memperpanjang periode penelitian, agar diperoleh sampel yang lebih banyak; menambahkan variabel lain seperti variabel yang diperkirakan dapat mempengaruhi Belanja Modal, variabel penerimaan daerah lainnya maupun variabel non-keuangan seperti tingkat pengangguran, pertumbuhan ekonomi, maupun luas wilayah. Saran bagi pemerintah sebaiknya kabupaten/kota di Provinsi Jawa Tengah lebih memperhatikan lagi potensi daerahnya agar tidak bergantung pada dana transfer dari pusat sebagai bentuk mewujudkan kemandirian daerah. Kemudian, membuka maupun meningkatkan potensi daerahnya sehingga 
nantinya mampu menunjang keuangan daerah yang pada akhirnya akan meningkatkan siklus perekonomian daerah dan perekonomian masyarakat juga.

\section{Daftar Pustaka}

Ramlan., Dr. Darwanis, M. Si, Ak.,\& Dr. Abdullah., Syukriy, SE,M.Si, Ak (2016). “Pengaruh Pajak Daerah, Retribusi Daerah, Lain-Lain PAD Yang Sah, Dan Dana Alokasi Khusus terhadap Belanja Modal(Studi pada Pemerintah Kab/Kota di Provinsi Aceh). Jurnal Magister Akuntansi Volume 5, No. 2, Mei 2016, ISSN 2302-0164.

Runtu V G., Walewangko E N., \& Tolosang K D (2016). “Pengaruh Pajak dan Retribusi terhadap Belanja Modal Kota Manado (periode 2005-2015)".Jurnal Berkala Ilmiah Efisiensi Volume 16 No. 03 Tahun 2016.

MS., M Zahari (2018). "Pengaruh Pajak Daerah dan Retribusi Daerah terhadap Belanja Modal di Kota Jambi". Jurnal Ilmiah Universitas Batanghari Jambi Vol.18 No.3 Tahun 2018.

Handayani., S P HS, dkk (2015). “Pengaruh Penerimaan Pajak Daerah, Retribusi Daerah dan Dana Bagi Hasil (DBH) terhadap Belanja Modaldi kab/kota di Provinsi Aceh". Jurnal Magister Akuntansi Pascasarjana Universitas Syiah Kuala Volume 4, No. 2, Mei 2015 ISSN 2302-0164.

Hassan Anggun., dkk (2016). "Pengaruh Dana Alokasi Umum, Pajak Daerah dan Retribusi Daerah terhadap Belanja Modal (studi di Kota Manado tahun 2005-2015). Jurnal Berkala Ilmiah Efisiensi Volume 16 No. 03 Tahun 2016.

SudikaI Komang.,\& Budiartha I Ketut (2017). “Pengaruh Pajak Daerah, Retribusi Daerah, Dana Alokasi Umum, dan Dana Alokasi Khusus pada Belanja Modal Provinsi Bali". Jurnal Akuntansi Universitas Udayana Vol.21.2. November (2017) ISSN: 2302-8556 E- 16891718.

Mamonto Sandry Yossi.,\& Tolosang J. B. Kalangi dan Krest D (2014).“ Pengaruh Pajak Daerah dan Retribusi Daerah terhadap Belanja Modal (Studi pada Kab Bolaang Mongondow Periode 2004-2013).Jurnal Fakultas Ekonomi dan Bisnis, Universitas Sam Ratulangi.

Permatasari, Isti (2016). "Pengaruh Pendapatan Daerah terhadap Belanja Modal Kabupaten/kota di Jawa Timur".Jurnal ilmu dan Riset Akuntansi Sekolah Tinggi Ilmu Ekonomi Indonesia, Surabaya Volume 5, nomor 1, Januari 2016. ISSN: 2460-0585.

Wandira, Arbie Gugus (2013). “Pengaruh PAD, DAU, dan DBH terhadap Pengalokasian Belanja Modal".Accounting Analysis Journal Fakultas Ekonomi Universitas Negeri Semarang.AAJ 2 (1) (2013). ISSN:2252-6765.

Martini, Ni Luh Dina Selvia., Cipta Wayan.,\& Suwendra Wayan I (2014). "Pengaruh Pendapatan Asli Daerah, Dana Alokasi Umum dan Dana Alokasi Khusus terhadap Belanja Modal pada Kab Buleleng tahun 2006-2012".

Nurdiwaty, Diah.,Zaman Badrus., Krisnawati Efda (2017)."Analisis Pengaruh Pertumbuhan Ekonomi, Pendapatan Asli Daerah, Dana Perimbangan, dan Lain-lain PAD yang sah terhadap Belanja Modal”.Jurnal Aplikasi Bisnis, Vol.17 No.1 Bulan Juli Tahun 2017. pISSN: 1411-4054/e-ISSN: 2579-3217.

Undang-Undang Nomor 28 tahun 2009 tentang Pajak Daerah dan Retribusi Daerah.

Peraturan Pemerintah Nomor 91 tahun 2010 tentang Jenis Pajak Daerah yang dipungut berdasarkan penetapan kepala daerah atau dibayar sendiri oleh wajib pajak. 
Peraturan Pemerintah Nomor 12 tahun 2019 pasal 33 ayat (4) Lain-lain pendapatan asli daerah yang sah.

Peraturan Pemerintah Nomor 55 tahun 2005 tentang Dana Perimbangan pada pasal 1 angka 24.

Undang-Undang Dasar 1945 Nomor 33 Tahun 2004 Pasal 1 Ayat 18 tentang Perimbangan Keuangan Antara Pusat dan Daerah.

Undang-Undang Dasar 1945 Nomor 32 Tahun 2004 pasal 1 ayat 7, 8 dan 9 tentang Pemerintah Daerah.

Peraturan Pemerintah Republik Indonesia Nomor 12 Tahun 2019 tentang Pengelolaan Keuangan Daerah.

Direktorat Jenderal Pajak Kementerian Keuangan Republik Indonesia Tahun 2017-2019 Tentang Daftar Realisasi APBD seluruh daerah di Indonesia. 